BULETINUL INSTITUTULUI POLITEHNIC DIN IAŞI

\section{sciendo}

DOI: $10.2478 / \mathrm{BIPMF}-2021-0008$
(BULLETIN OF THE POLYTECHNIC INSTITUTE FROM IAȘI)

Published by "Gheorghe Asachi" Technical University of Iasi

Volume 67(71), No. 2, 2021

Section Mathematics Theoretical Mechanics. Physics

\title{
A COMPARATIVE STUDY OF THE PROPERTIES OF DIFFERENT "LICHID WOOD” PRESENTATION FORMS
}

\author{
DORIN VĂIDEANU ${ }^{1, *}$ and TUDOR-CRISTIAN PETRESCU ${ }^{2}$ \\ 1"Alexandru Ioan Cuza" University of Iaşi, \\ Department of Natural Sciences and Mathematics, Iaşi, Romania \\ 2"Gheorghe Asachi”" Technical University of Iaşi, \\ Department of Structural Mechanics, Iaşi, Romania
}

Received: April 22, 2021

Accepted for publication: June 2, 2021

\begin{abstract}
The existence of many forms of "liquid wood", even in the same subgroup, is explained by the fact that the main matrix is made of lignin and lignin can be found in nature in over 60 presentation forms. The lignin molecule is a complex macro - molecule made of three molecules which link together in various shapes. At the same time, structurally speaking, the lignin molecule is dependent on the type of plant species from which it is sourced. It results that the type and the structure of the lignin molecule - and implicitly the "liquid wood" biocomposite matrix - has a major role in the forming and the structuring of every type of "liquid wood". In the current article, a comparative study of the properties of "liquid wood" pertaining to all three subgroups is presented. The chosen types are: Arboform F45, Arbofill Fichte and Arboblend V2 (which is the subject of the entire study).
\end{abstract}

Keywords: Arboblend; Arbofill; Arboform; thermodynamic; structural.

*Corresponding author; e-mail: naturaone@gmail.com (C) 2021 Văideanu D. et al. This is an Open access article licensed under the Creative Commons Attribution-Non Commercial - No Dericatives 4.0 International License (CC BY-NV-ND 4.0) 


\section{Introduction}

The generically - named composite "liquid wood" is manufactured in three distinct subgroups: Arboform, Arbofill and Arboblend. Each of these three subgroups contains several presentation forms (e.g. the Arboblend subgroup exhibits: Arboblend V1, Arboblend V2, Arboblend V3, Arboblend V4 and Arboblend V5). All these presentation forms have common characteristics that allow the three distinct subgroups to be assimilated to biocomposites. The existence of many forms of "liquid wood", even in the same subgroup, is explained by the fact that the main matrix is made of lignin and lignin can be found in nature in over 60 presentation forms. The lignin molecule is a complex macro - molecule made of three molecules which link together in various shapes.

\section{Results and Discussions}

\subsection{A Comparative Study of Mechanical Properties}

In the comparative study of the mechanical properties for the three previously - mentioned materials, several criteria were established: testing was made on the same universal testing apparatus ZWIEK - ROELL 2005, in the same temperature and humidity conditions, and it was attempted, as much as possible, for the samples to be obtained in the same injection conditions. The variation of the elastic force is presented in the graphs in Fig. $1 a, b, c$. 


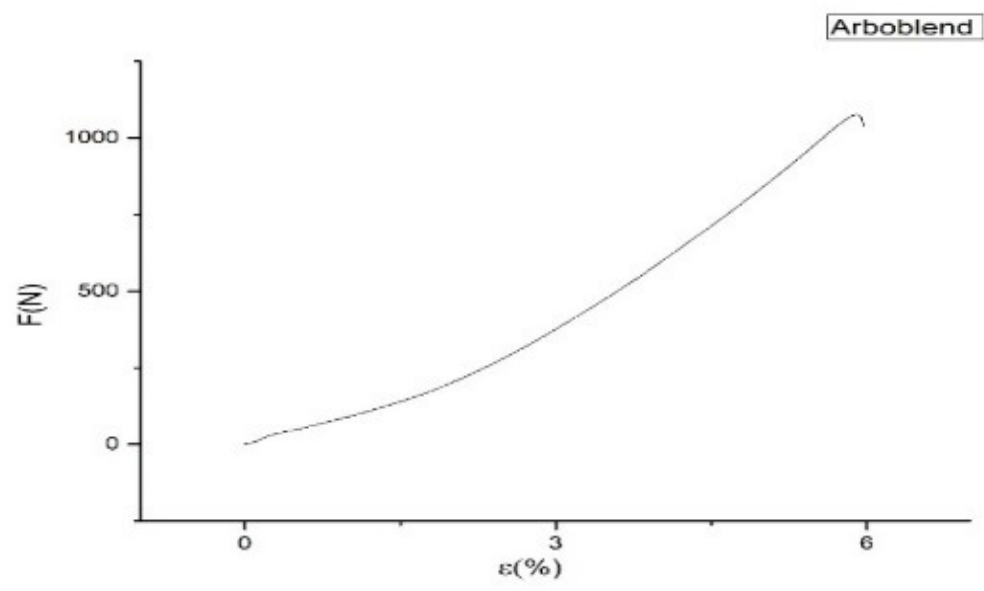

Fig. $1 a-$ The variation of the elastic force depending on the relative elongation for Arboblend V2.

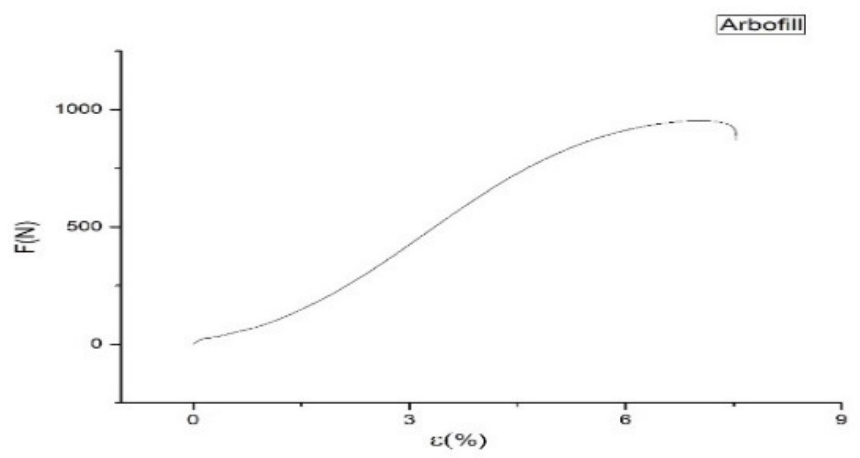

Fig. $1 b-$ The variation of the elastic force depending on the relative elongation for Arbofill Fichte (Puiu Costescu, 2018). 


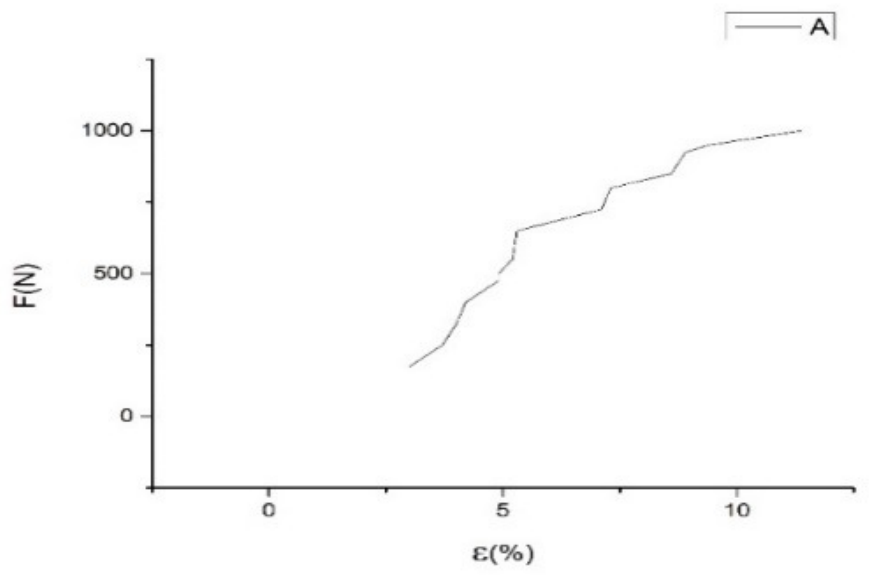

Fig. $1 c-$ The variation of the elastic force depending on the relative elongation for Arboform F45 (Plăvănescu et al., 2015).

The most important observations which can be made following the analysis of the graphs are:

The biggest traction resistance for Arboblend was obtained on sample $14 \mathrm{Ab}$, for which the injection parameters were: melting temperature $\mathrm{T}_{\text {top }}=170^{\circ} \mathrm{C}$, injection angle $\alpha=90^{\circ}$, injection pressure $P_{\text {inj }}=90 \mathrm{Mpa}$, injection time $t_{\text {inj }}=6 \mathrm{~s}$, cooling time $t_{r}=25 \mathrm{~s}$ and injection speed $v_{\text {inj }}=90 \mathrm{~m} / \mathrm{min}$.

The values obtained following traction testing were: breaking strength $\mathrm{R}=1035,9 \mathrm{~N}$, quasielastic coefficient $\mathrm{R}_{\mathrm{m}}=278,51 \mathrm{~N} / \mathrm{mm}$ and absolute elongation $\Delta \mathrm{l}=4.757 \mathrm{~mm}$.

For Arbofill, the biggest traction resistance was obtained on sample 13Al, for which the injection parameters were: melting temperature $\mathrm{T}_{\text {top }}=155^{\circ} \mathrm{C}$, injection angle $\alpha=0^{\circ}$, injection pressure $P_{\text {inj }}=90 \mathrm{Mpa}$, injection time $t_{\text {inj }}=6 \mathrm{~s}$, cooling time $t_{r}=18 \mathrm{~s}$ and injection speed $v_{\text {inj }}=80 \mathrm{~m} / \mathrm{min}$.

In this case, the obtained values for traction testing were: breaking stregth $R=1041,9 \mathrm{~N}$, quasileastic coefficient $\mathrm{R}_{\mathrm{m}}=278,31 \mathrm{~N} / \mathrm{mm}$ and absolute elongation $\Delta \mathrm{l}=4.75 \mathrm{~mm}$.

Another important observation is the fact that quasielastic properties for the mentioned materials emerge when an external force appears. The appearance of these inflection points can be explained by means of the deformation resistance of the material.

Because "liquid wood" can be assimilated with a complex system, the usual Hooke's Law:

$$
\sigma=E \varepsilon
$$

must be replaced with a power - type law: 


$$
\bar{\sigma}=\bar{E}(\bar{\varepsilon})^{\alpha}
$$

where $\bar{\sigma}$ corresponds to fractal tension, $\bar{\varepsilon}$ corresponds to fractal deformation, $\bar{E}$ represents the equivalent of Young's modulus, and $\alpha$ is a fractionary coefficient linked to the fractality degree of the elongation curves.

Because $\bar{\sigma}, \bar{\varepsilon}$ are fractal variables and $\bar{E}$ is a Young - type fractal coefficient, they will be complex parameters. Their real part is differentiable and scale resolution - independent and their imaginary part is non differentiable and scale resolution - dependent.

Moreover, $\bar{\sigma}$ and $\bar{\varepsilon}$ are simultaneously invariant parameters with respect to both scale and space - time transformations.

As such, in a certain context, the appearance of inflection "points" is nothing else than modifications of the fractality degree of the flow curves.

Regarding the comparative study of the impact resistance for the three materials which are made of "liquid wood", the obtained results are highlighted in the following tables and graphs:

In Fig. $2 a, b, c$ the variation of the impact resistance of the samples can be observed.

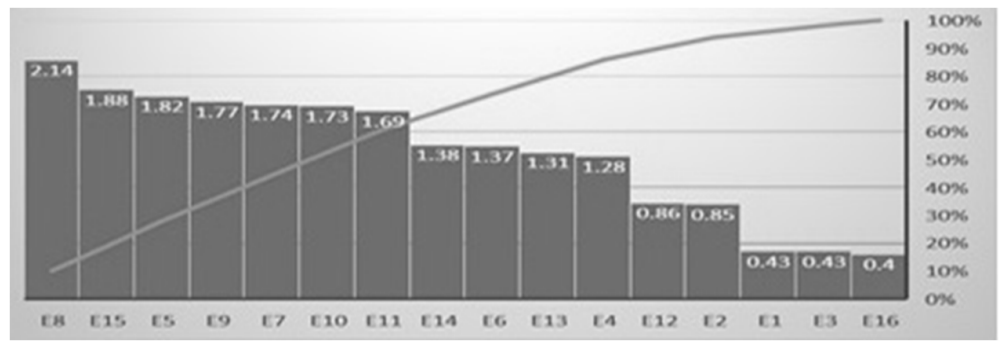

Fig. $2 a$ - The diagram of impact resistance for Arboblend V2.

The sample E16 exhibited the highest resilience, with the following injection parameters: melting temperature $T_{t}=155^{\circ} \mathrm{C}$, injection angle $\alpha=90^{\circ}$, injection pressure $P_{i n j}=90 \mathrm{Mpa}$, injection time $t_{\mathrm{i}}=6 \mathrm{~s}$, cooling time $t_{\mathrm{r}}=25 \mathrm{~s}$ and injection speed $v_{\text {inj }}=60 \mathrm{~m} / \mathrm{min}$.

From the analysis of the graphs, it is possible to observe the variation of impact resistance, the obtained values being influenced by the injection parameters of the studied materials. 


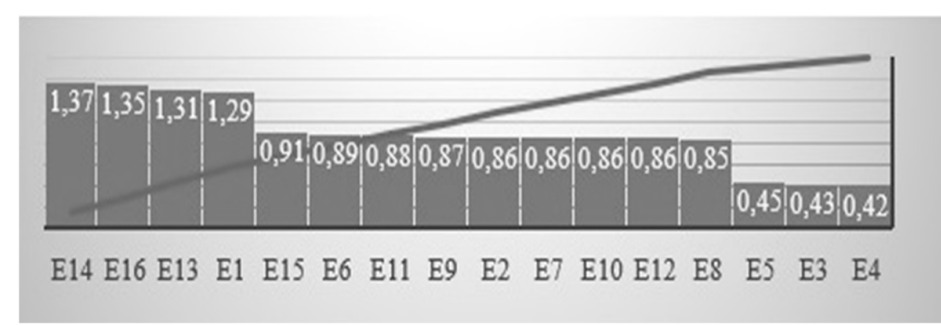

Fig. $2 b$ - The diagram of impact resistance for Arbofill Fichte (Puiu Costescu, 2018).

The sample E4 exhibited the highest resilience, with the following injection parameters: (according to Annex 2) were: melting temperature $T_{t}=140^{\circ} \mathrm{C}$, injection angle $\alpha=0^{\circ}$, injection pressure $p_{i n j}=70 \mathrm{Mpa}$, injection time $t_{i}=6 \mathrm{~s}$, cooling time $t_{r}=25 \mathrm{~s}$, and injection speed $v_{\text {inj }}=60 \mathrm{~m} / \mathrm{min}$.

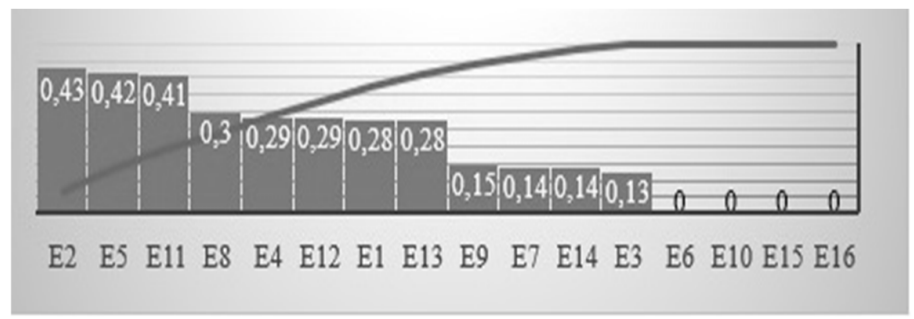

Fig. $2 c$ - The diagram of impact resistance for Arboform F45 (Nedelcu, 2014).

The sample E4 exhibited the highest resilience, with the following injection parameters: (according to Annex 2) were: melting temperature $\mathrm{T}_{\mathrm{t}}=140^{\circ} \mathrm{C}$, injection angle $\alpha=0^{\circ}$, injection pressure $p_{\text {inj }}=90 \mathrm{Mpa}$, injection time $t_{i}=9 \mathrm{~s}$, cooling time $t_{r}=18 \mathrm{~s}$, and injection speed $v_{\text {inj }}=60 \mathrm{~m} / \mathrm{min}$ (Nedelcu, 2014).

It is known that lignin is the substance which lends both elasticity and hardness to the wooden fiber. This viscoelastic hardness can be explained by the fact that the lignin molecule is a complex molecule made of three complex molecules which, depending on the external deformation action, "seek" to shorten the chemical bonds between them, in such a way as the final lignin molecule will occupy the same volume.

Depending on the injection parameters (and especially on the direction of the injection angle), the link which exists between the values of the viscoelastic properties and the settling mode of the molecular lignin chain, transversally or longitudinally, can be observed.

For null values of shock resistance, it can be concluded that the material is brittle, as it does not resist in any way to external mechanical action. In this case, it can be stated that the molecular lignin chain is settled in parallel with the direction of propagation of the external mechanical action. This aspect may be 
used in the case where mechanical cutting of parts from the respective material is in question, as no significant inner structural changes of the material take place.

\subsection{The Comparative Study of Thermodynamic and Structural Properties}

The comparative study of the thermodynamic properties was made with a differential scanning calorimeter DSC Netzsch STA 449 F1 Jupiter having a Proteus software suite, which allowed the drafting on the heating curves for the studied samples. In Fig. $3 a, b, c$ the curves that were obtained following the heating process of the samples can be observed:

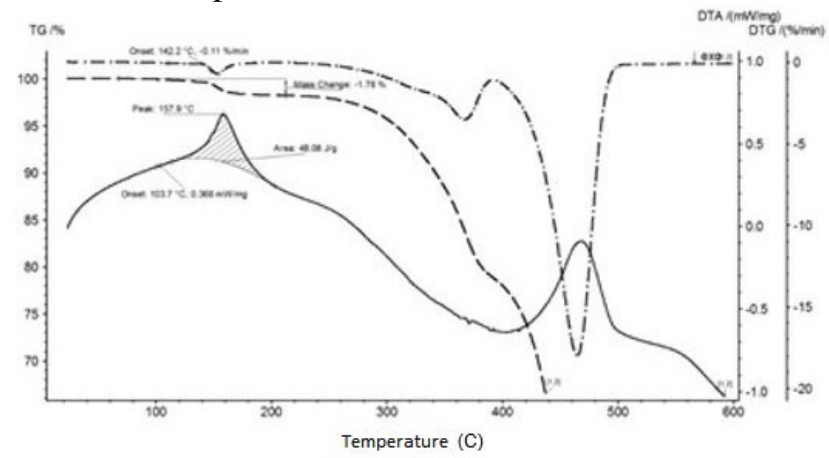

Fig. $3 a$ - Heating curve graph for Arboblend V2 (Puiu Costescu, 2018).

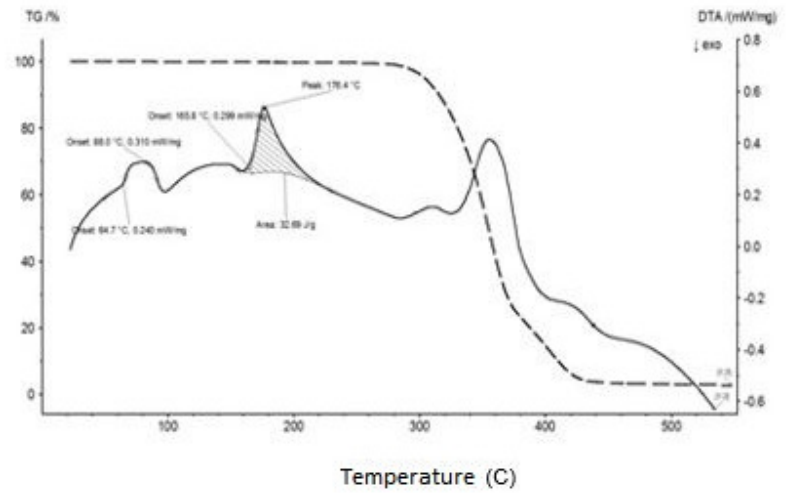

Fig. $3 b$ - Heating curve graph for Arbofill Fichte (Puiu Costescu, 2017).

It can be observed that in the temperature interval $64.7^{\circ} \mathrm{C}-88.0^{\circ} \mathrm{C}$ a second order transformation exists, which most probably corresponds to a change in the internal structure. The melting temperature is approximately $176.4^{\circ} \mathrm{C}$ and around the temperature of $380^{\circ} \mathrm{C}$ the sample suddenly looses mass corresponding to a maximum of internal energy, which point to the fact that the evaporation of the substance takes place. 


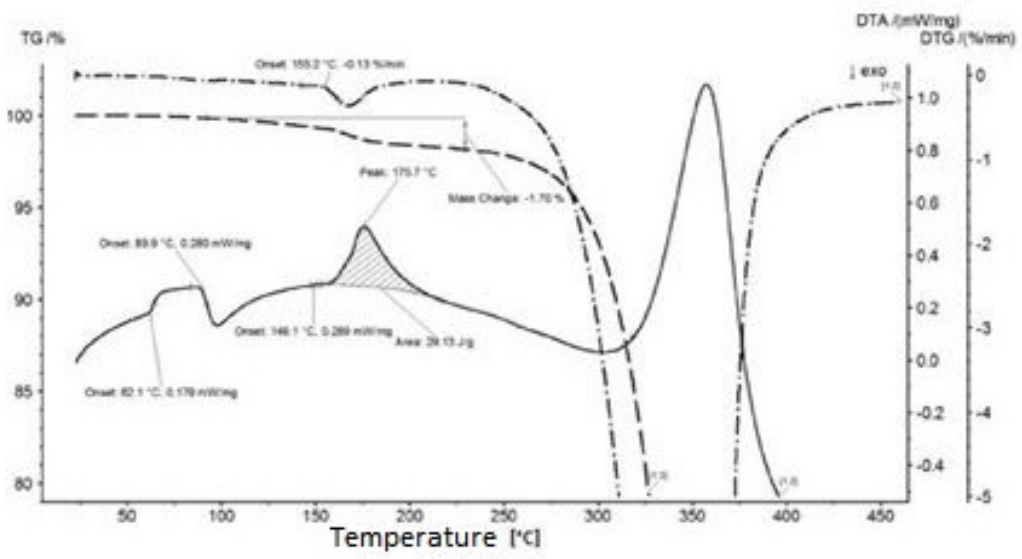

Fig. 3c-Heating curve graph for Arboform F45 (Plăvănescu, 2017).

In the DSC graph for Arboform F45, the same phase transformation may be observed with a change in internal structure, but it takes place in the $62.1^{\circ} \mathrm{C}-89.9^{\circ} \mathrm{C}$ temperature interval. At the temperature of $155.2^{\circ} \mathrm{C}$ the sample loses $13 \%$ of its mass - possibly water and at the temperature of $175.7^{\circ} \mathrm{C}$ the melting of the material takes place. For Arboform, the complete substance evaporation takes place at two different temperature values, $325^{\circ} \mathrm{C}$ and $355^{\circ} \mathrm{C}$, which can be explained by the separate evaporation of the material components.

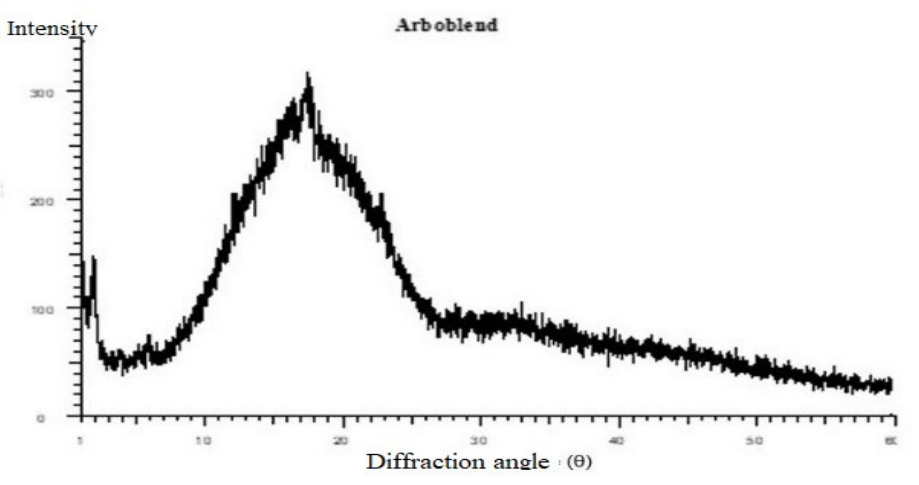

Fig. 4a-XRD diffraction graph for Arboblend V2 sample (Puiu Costescu, 2018). 


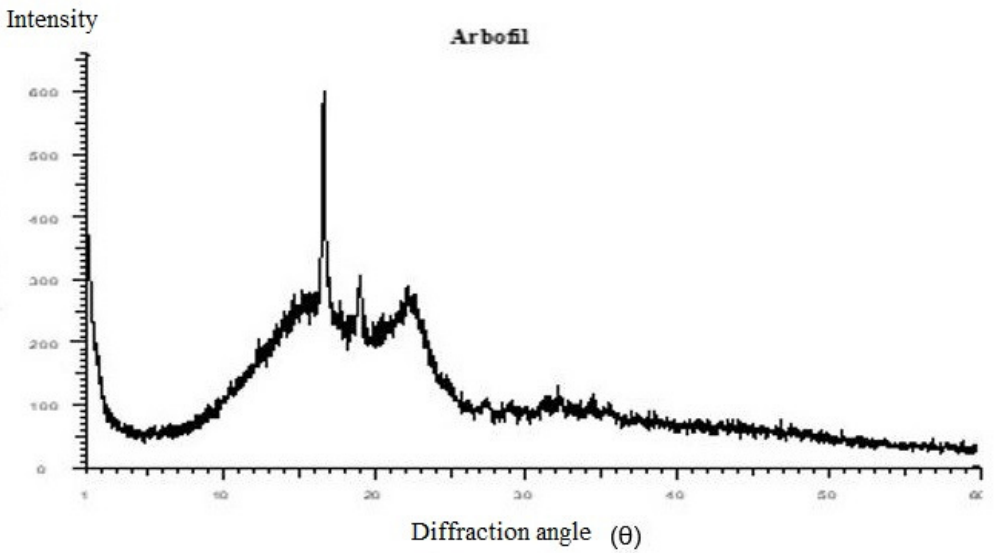

Fig. $4 b$ - XRD diffraction graph for Arbofill Fichte sample (Puiu Costescu, 2017).

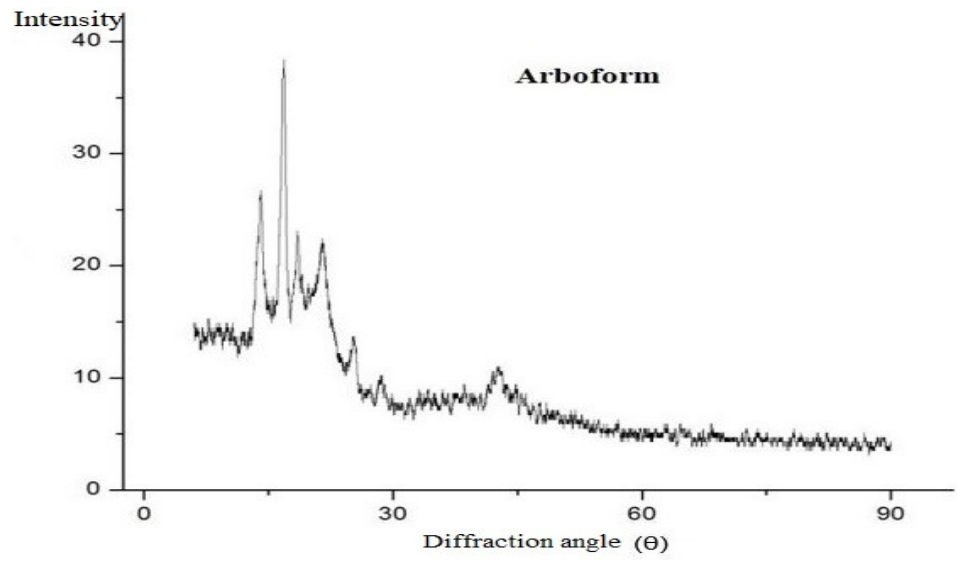

Fig. $4 c-$ XRD diffraction graph for Arboform F45 sample (Plăvănescu, 2017).

In Fig. $4 b$ and $4 c$ it can be observed that Arbofill Fichte and Arboform F45 show diffraction peaks, which prove the existance of crystalline domains for the two materials.

In the case of Arboblend V2 (Fig. 4a), there are no diffraction peaks, so said material is an amorphous one (Plăvănescu Mazurchevici, 2015).

The different behavior corresponding to different "liquid wood" presentation forms lead to the idea of determining the chemical groups which make up the respective materials by means of FTIR. Following the study, the graphics show in Fig. $5 a, b, c$ were obtained. 


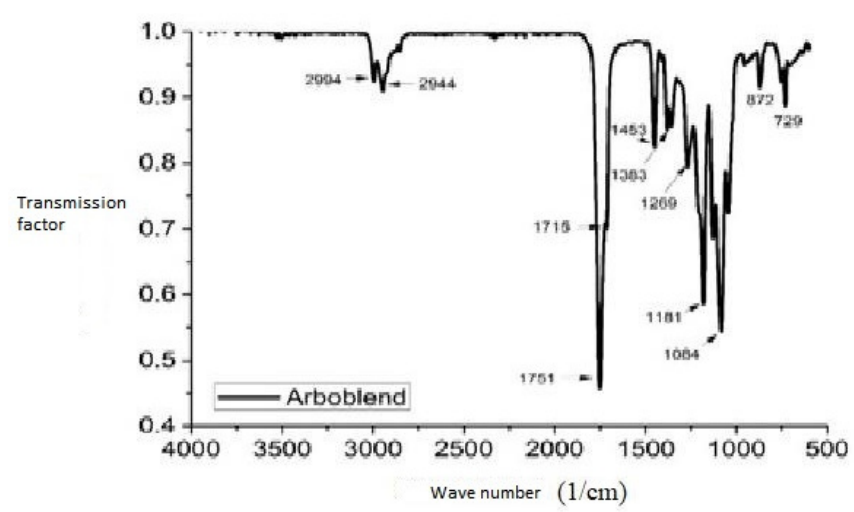

Fig. 5a-FTIR (Fourier Transform Infrared Spectroscopy) graph for Arboblend V2 sample (Puiu Costescu, 2018).

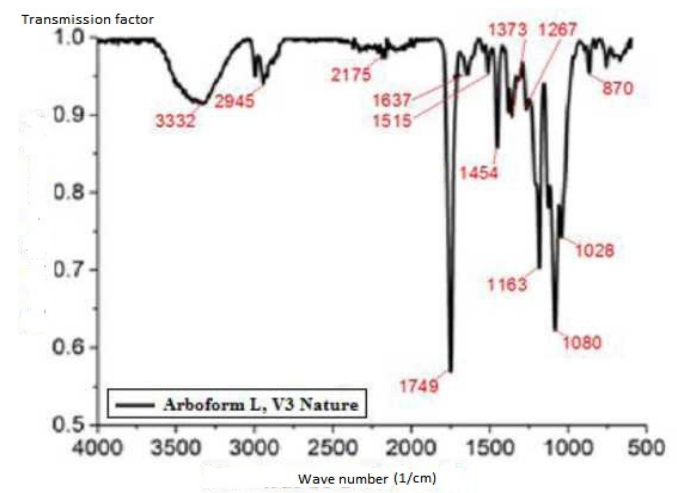

Fig. 5b-FTIR (Fourier Transform Infrared Spectroscopy) graph for Arboform F45 sample (Plăvănescu, 2017).

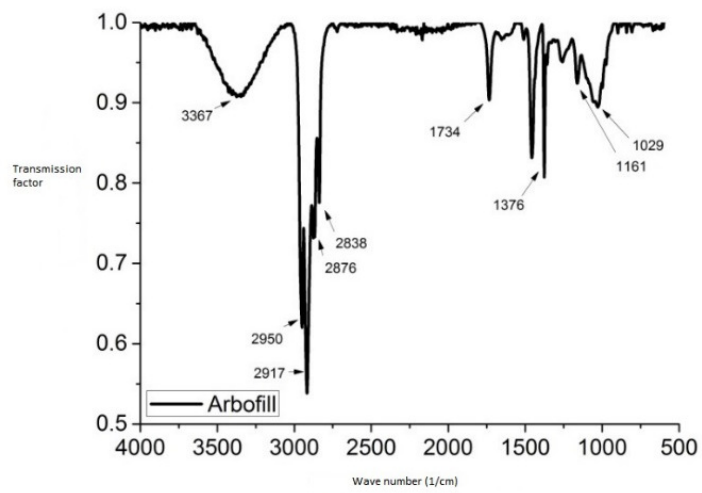

Fig. 5c-FTIR (Fourier Transform Infrared Spectroscopy) graph for Arbofill Fichte sample 6 (Puiu Costescu, 2018). 
From the analysis of the graphs, the chemical groups and eventual chemical substances present in the respective materials were determined. In Tables 1 a,b,c the results obtained from the spectral analysis are presented, (Puiu Costescu, 2018; Plăvănescu, 2017).

Table 1a

The Identification of Groups and Chemical Substances According to the "Peak Value" of Arboblend V2

\begin{tabular}{||l|l|l||}
\hline Arboblend V2 & Existing chemical groups & $\begin{array}{l}\text { Potential existing } \\
\text { chemical substances }\end{array}$ \\
\hline \hline $2944(2943)$ & Assymetric $(\mathrm{CH})$ vibration stretch & \\
\hline $1751(1752)$ & $\mathrm{C}=$ O stretch & Lignin derivatives \\
\hline $1715(1713)$ & $\begin{array}{l}\text { Amide I; stretch vibrations } \mathrm{C}=\mathrm{O} \text { in } \\
\text { urethane }\end{array}$ & \\
\hline $1084(1085)$ & Stretch vibrations $\mathrm{C}-\mathrm{O}$ in ester & $\begin{array}{l}\text { Lignin and } \\
\text { hemicellulose }\end{array}$ \\
\hline $1269(1375)$ & $\mathrm{CO}$ stretching & Lignin \\
\hline $1453(1454)$ & $\mathrm{CH}$ stretching & Lignin derivatives \\
\hline $872(873)$ & $\mathrm{CH} 2$ & Lignin derivatives \\
\hline \hline $729(730)$ & $\mathrm{C}-\mathrm{H}$ & \\
\hline
\end{tabular}

Table 1b

The Identification of Groups and Chemical Substances According to the "Peak Value" of Arbofill Fichte (Puiu Costescu, 2018)

\begin{tabular}{|c|c|c|}
\hline Arbofill Fichte & Existing chemical groups & $\begin{array}{l}\text { Potential existing } \\
\text { chemical substances }\end{array}$ \\
\hline 2917 (2916) & Stretch vibrations $(\mathrm{CH})$ sim & \\
\hline $\begin{array}{l}1734(1732) \\
\text { Or } \\
(1735)\end{array}$ & $\begin{array}{l}\text { Stretch vibrations } \mathrm{C}=\mathrm{O} \text { in ester or } \\
\text { is stretched in ketones, non-conjugated } \\
\text { aldehydes and carboxyl group }\end{array}$ & $\begin{array}{l}\text { Xylan and } \\
\text { hemicellulose }\end{array}$ \\
\hline $1376(1376)$ & $\begin{array}{l}\text { Deformation vibrations (shear, } \\
\text { bending) } \mathrm{CH}_{2} \text { bending and deformation }\end{array}$ & \\
\hline $1161(1163)$ & $\begin{array}{l}\text { COC stretching of asymmetric oxygen } \\
\text { bridge }\end{array}$ & Cellulose \\
\hline $1376(1375)$ & bending $\mathrm{CH}$ & Cellulose \\
\hline $1029(1028)$ & $\begin{array}{l}\mathrm{C}-\mathrm{C}, \mathrm{C}-\mathrm{OH}, \mathrm{C}-\mathrm{H} \text { ring and lateral } \\
\text { vibration group }\end{array}$ & Hemicellulose, Pectin \\
\hline
\end{tabular}


Table 1c

The Identification of Groups and Chemical Substances According to the "Peak Value" of Arboform F45 (Plăvănescu, 2017)

\begin{tabular}{||l|l|l||}
\hline Arboform F45 & Existing chemical groups & $\begin{array}{l}\text { Potential existing } \\
\text { chemical substances }\end{array}$ \\
\hline \hline 870 & C-H; CH2 & $\begin{array}{l}\text { correlated with the } \\
\text { ester part }\end{array}$ \\
\hline 1028 & $\begin{array}{l}\text { C-C, C-OH, C-H ring and lateral } \\
\text { vibration group }\end{array}$ & $\begin{array}{l}\text { Hemicellulose, } \\
\text { Pectin }\end{array}$ \\
\hline 1080 & Stretch/elongation vibrations in ester & $\begin{array}{l}\text { Polyether, } \\
\text { Lignin derivatives }\end{array}$ \\
\hline 1163 & $\begin{array}{l}\text { C-O-C asymmetric stretching of oxygen } \\
\text { bridge }\end{array}$ & Cellulose \\
\hline 1267 & Stretch/elongation vibrations C-O & Lignin and cellulose \\
\hline 1373 & Deformation vibrations (bending) C-H & Cellulose \\
\hline
\end{tabular}

In Tables $2 a, b, c$ the values for the wavelengths for which the maximum vibrations (resonance) take place are presented.

Table 2a

The Values for the Wavelengths for which the Maximum Vibrations (Resonance) for Arboblend V2 take place

\begin{tabular}{||l|l|l||}
\hline $\begin{array}{c}\text { Wave number } \\
\left(\mathrm{cm}^{-1}\right)\end{array}$ & \multicolumn{1}{|c||}{$\begin{array}{c}\text { Existing chemical } \\
\text { groups }\end{array}$} & \multicolumn{1}{c||}{ Potential existing substances } \\
\hline \hline $2944-2994$ & $\mathrm{O}-\mathrm{H}$ & $\begin{array}{l}\text { Lignin derivatives, polyesters, alcohols, } \\
\text { water traces }\end{array}$ \\
\hline $1715-1751$ & $\mathrm{C}=\mathrm{O}$ & $\begin{array}{l}\text { Lignin derivatives, polyhydroxyalkanoates, } \\
\text { polyesters }\end{array}$ \\
\hline 1453 & $\mathrm{CH}_{2}$ & bending \\
\hline $1376-1383$ & $\mathrm{CH}_{2}$ & wagging \\
\hline 1269 & $\mathrm{C}(\mathrm{O})-\mathrm{O}$ & Asymmetric stretching, polyesters \\
\hline $1161-1181$ & $\mathrm{C}(\mathrm{O})-\mathrm{O}$ & Symmetric stretching, polyesters \\
\hline $1029-1084$ & $\mathrm{C}-\mathrm{C}-\mathrm{O} ; \mathrm{C}-\mathrm{O}-\mathrm{C}$ & Polyethers, lignin derivatives \\
\hline $729-872$ & $\mathrm{C}-\mathrm{H} ; \mathrm{CH}$ & $\begin{array}{l}\text { Other variants may occur; } \\
\text { They seem to be correlated with the ester } \\
\text { part }\end{array}$ \\
\hline
\end{tabular}


Table 2b

The Values for the Wavelengths for which the Maximum Vibrations (Resonance) for Arbofill Fichte Take Place (Puiu Costescu, 2018)

\begin{tabular}{|l|l|l||}
\hline $\begin{array}{c}\text { Wave number } \\
\left(\mathrm{cm}^{-1}\right)\end{array}$ & \multicolumn{1}{|c||}{$\begin{array}{c}\text { Existing } \\
\text { chemical groups }\end{array}$} & \multicolumn{1}{c|}{ Potential existing substances } \\
\hline \hline $3330-3367$ & $\mathrm{O}-\mathrm{H}$ & $\begin{array}{l}\text { lignin derivatives, polyesters, alcohols, water } \\
\text { traces }\end{array}$ \\
\hline $2838-2950$ & $\mathrm{C}-\mathrm{H}$ & $\begin{array}{l}\text { lignin derivatives, polyolefins (polyethylene, } \\
\text { polypropylene, etc), polyhydroxyalkanoates, } \\
\text { polyesters, etc. }\end{array}$ \\
\hline $1715-1751$ & $\mathrm{C}=\mathrm{O}$ & $\begin{array}{l}\text { lignin derivatives, polyhydroxyalkanoates, } \\
\text { polyesters }\end{array}$ \\
\hline 1643 & $\mathrm{C}=\mathrm{O}$ & linked through hydrogen links \\
\hline 1511 & & possible aromatic lignin ring \\
\hline 1453 & $\mathrm{CH} 2$ & bending \\
\hline $1376-1383$ & $\mathrm{CH} 2$ & wagging \\
\hline 1269 & $\mathrm{C}(\mathrm{O})-\mathrm{O}$ & asymmetric stretching, polyesters \\
\hline $1161-1181$ & $\mathrm{C}(\mathrm{O})-\mathrm{O}$ & symmetric stretching, polyesters \\
\hline $1029-1084$ & $\mathrm{C}-\mathrm{C}-\mathrm{O} ; \mathrm{C}-\mathrm{O}-\mathrm{C}$ & polyethers, lignin derivatives \\
\hline $729-872$ & $\mathrm{C}-\mathrm{H} ; \mathrm{CH} 2$ & other variants are possible; ester part \\
\hline
\end{tabular}

Table 2c

The Values for the Wavelengths for which the Maximum Vibrations (Resonance) for Arboform F45 Take Place (Plăvănescu, 2017)

\begin{tabular}{||l|l|l||}
\hline $\begin{array}{c}\text { Wave number } \\
\left(\mathrm{cm}^{-1}\right)\end{array}$ & \multicolumn{1}{|c||}{ Existing chemical groups } & \multicolumn{1}{|c|}{$\begin{array}{c}\text { Potential existing } \\
\text { substances }\end{array}$} \\
\hline \hline 1454 & Deformation vibrations (bending) $\mathrm{CH} 2$ & lignin \\
\hline 1515 & $\mathrm{C}=\mathrm{C}$ aromatic ring stretch & lignin \\
\hline 1637 & $\mathrm{H}_{2} \mathrm{O}$ (water) & cellulose \\
\hline 1749 & $\mathrm{C}=$ O non-conjugated elongation/stretch & $\begin{array}{l}\text { hemicellulose, } \\
\text { xylan }\end{array}$ \\
\hline 2175 & $\mathrm{C}=\mathrm{C}$ Stretch/elongation vibrations & alkynes \\
\hline 2945 & $\begin{array}{l}\text { Stretch/elongation vibrations }(\mathrm{CH}) \\
\text { asymmetric }\end{array}$ & $\begin{array}{l}\text { lignin derivatives, } \\
\text { polyolefins }\end{array}$ \\
\hline 3332 & stretch/elongation O-H & $\begin{array}{l}\text { a-cellulose (lignin } \\
\text { derivatives, water) }\end{array}$ \\
\hline
\end{tabular}

The main observations are listed below, but they also caryy a degree of uncertainty, because the manufacturer, in his published patents, does not offer exact data regarding the composition of the materials (the indicated lignin percentage is listed as the interval [60\%-99\%]), (Puiu Costescu, 2018).

The samples do not seem to contain any polymers with amine and/or amide functions. The very strong signal emitted by the hydrocarbonate chains, 
to the detriment of polyester and polyether $\mathrm{C}-\mathrm{O}$ links seems to indicate a complete replacement of said links with integral polymers or at least with polymers made mostly of hydrocarbonate links (for example, polyolefins such as polyethylene or polypropylene).

\section{Conclusions}

The conclusions which resulted following the studies made regarding the mechanical behavior of Arboblend, Arbofill and Arboform are the following:

For certain injection parameters and for small forces, inflection points may appear, for a certain value of the deformation force.

Lignin is the substance which lends hardness to the wooden fiber; at the same time, the lignin molecule is a complex molecule made by the coupling of three macromolecules. The appearance of the inflection points can be explained through the resistance of the material to deformation, which is given by the spatial reconfiguration of the lignin molecules, which seek to shorten the chemical bonds between the atoms.

The increase of the mechanical resistance of the studied materials can be obtained by optimizing the injection parameters (Puiu Costescu, 2018).

The modification in time of the dimensions of several samples can be explained by means of a flow phenomenon with a very high viscosity coefficient, which decreases along with an increase in temperature.

The appearance of second order phase transformations for Arbofill Fichte and Arboform F45 can be corroborated with the structural analysis performed using X-Ray diffraction and with the statements of the manufacturer, which specify the fact that these two materials have a quasicrystalline structure.

The analysis of the X-Ray diffraction graph clearly highlights that, for the two materials, a quasicrystalline phase exists, unlike in the case of Arboblend V2, which does not exhibit such a phase, Fig. 4 a,b,c.

The weak carbonyl signal of $1734 \mathrm{~cm}^{-1}$ certifies the presence of lignin and/or other carbonyl additives.

The FTIR analysis confirms the corresponding composition of biodegradable natural materials for the studied presentation forms.

\section{REFERENCES}

Nedelcu D., Plăvănescu S., Puiu E., Impact Resistance of "Liquid Wood”, Proceedings of ModTech2014 International Conference, July 13-16, Gliwice, Poland, Advanced Materials Research, 2014, Vol. 1036, 13-17.

Plăvănescu S., Quadrini F., Nedelcu D., Tensile Test for Arboform Samples, Acta Universitatis Cibiniensis-Technical Series, 2015, 66(1), doi: 10.1515/aucts2015-0044, 147-152. 
Plăvănescu (Mazurchevici) S., "Liquid Wood" as a Sustainable Material, The Second CommScie International Conference: "Challenges for Sciences and Society in Digital Era", 4-5 decembrie, 2015, Iaşi, Romania, 90-93.

Plăvănescu (Mazurchevici) S., Contributions to the Study of the Obtaining Process of Reinforced Parts of Materials Biodegradable by Injection, Doctoral Thesis Gheorghe Asachi Technical University of Iaşi, 2017.

Puiu (Costescu) E., Behavior Contributions Biocomposites in the Injection Process Doctoral Thesis "Gheorghe Asachi”" Technical University of Iaşi, 2018.

Puiu (Costescu) E., Văideanu D., Băcăiță S., Agop M., Thermal and Electrical Behaviors of the Arbofill Liquid Wood, International Journal of Modern Manufacturing Technologies, 4, 1, 79-83 (2017).

\section{STUDIU COMPARATIV A PROPRIETĂȚILOR DIFERITELOR FORME DE PREZENTARE ALE „LEMNULUI LICHID”}

(Rezumat)

Existența a mai multe forme de „lemn lichid”, chiar și în aceeași subgrupă, se explică prin faptul că matricea principală este formată din lignină, iar lignina se găsește în natură în peste 60 de forme de prezentare. Molecula de lignină este o macro moleculă complexă formată din trei molecule care se leagă între ele în diferite forme. În același timp, din punct de vedere structural, molecula de lignină depinde de tipul de specii de plante din care provine. Rezultă că tipul și structura moleculei de lignină - şi implicit matricea biocompozită a „lemnului lichid” - are un rol major în formarea şi structurarea fiecărui tip de „lemn lichid”. În acest articol, este prezentat un studiu comparativ al proprietăților „lemnului lichid” care aparțin tuturor celor trei subgrupuri. Tipurile alese sunt: Arboform F45, Arbofill Fichte și Arboblend V2 (care face obiectul prezentului studiu). 